\title{
Getting into Fishing: Recruitment and Social Resilience in North Norfolk's ‘Cromer Crab' Fishery, UK
}

Carole Sandrine White, School of International Development, University of East Anglia, Norwich, Norfolk NR4 7T, UK.

Email: carole.white@uea.ac.uk

NB: This is the accepted manuscript for publication in May 2015. Do not cite this version.

In order to cite this article please check Sociologia Ruralis, Special Issue, July 2015 and download the published version here:

http://onlinelibrary.wiley.com/doi/10.1111/soru.12101/abstract

Or contact the author by emailing carole.white@uea.ac.uk for a copy. 
Abstract

The intergenerational continuity of fishing communities is a growing concern for the sustainability of small-scale fisheries around Europe. This is exemplified through the case of an English crab fishery where young people are being encouraged into fishing through funded training programmes with limited success. Opportunities for work have declined, most notably through a reduction in crew size to save costs. Interviews with fishermen of different ages are explored using access theory to elucidate how the social reproduction of fishing has changed. This shows how the agency of young aspiring fishermen is increasingly constrained by regulatory and financial factors. Improved social and spatial mobility among fishing families mean that recruitment into the fishery through a father-to-son pathway is increasingly uncommon. Youngsters from non-fishing families face additional financial and relational barriers. Funded courses cannot, on their own, provide a solution. A holistic approach to rural coastal development is required to build social resilience in fishing communities across Europe faced with similar problems.

\section{Introduction}

The lack of younger generations taking up commercial fishing is a growing issue in European and other fisheries worldwide with considerable implications for the sustainability of the industry. Not only does it pose questions for the survival of individual enterprises and put at risk local ecological knowledge, skills and fishing heritage, but it also deprives the industry of future sources of innovation, adaptability and enterprise. In this paper, the case of the North Norfolk "Cromer Crab" fishery - a small-scale fishery in the East of England - is examined to illustrate how and why the recruitment of young fishermen is failing.

Commercial fishing has generally declined in the United Kingdom since the late 1980s (MMO Statistics, 2014) following restructuring policies to address overcapacity (Hatcher, 1997). Debates on fisheries policy have narrowly focused on managing the natural resource and repeatedly ignored social considerations in order to achieve sustainable fisheries (Symes and Phillipson, 2009). Based on the deterministic premise that limiting fishing pressure will lead to improve resource productivity, it also assumes more profitable individual enterprises and better off coastal communities (NEF, 2012). However, it is far from clear whether after a period of contraction, the industry will still be able to attract and recruit fishermen who could reap the benefits when stocks recover. 
The question of sustainability addressed here focuses on the intergenerational continuity and the social reproduction of fishing. These issues have been raised in rural agricultural and fisheries sectors (reviewed in White, 2012 and in Symes and Frangoudes, 2001 respectively) and recent research has come from fisheries in Brazil, Canada and Norway (Neis et al., 2013; Sønvisen, 2013; Trimble and Johnson, 2013). This paper provides one of the first empirical contributions addressing this question in the United Kingdom. It aims to broaden the debate on sustainable and resilient fisheries to include intergenerational dimensions across the rural economy.

The research context and problematic is developed in Section 2 before introducing the conceptual framework and methodology (Section 3). An analysis of the recruitment process and pathways into fishing follows (Section 4 and 5). The Conclusion (Section 6) reflects on the implications of the findings for social reproduction and resilience building, and the actions needed to improve recruitment in fisheries particularly in the European Union.

\section{Research context and problematic}

The North Norfolk crab and lobster fishery involves 48 boats, mostly under 10 metres in length, and around 75 fishermen ${ }^{1}$ of whom over a third work part-time (IFCA pers comm., 2013). This includes small, beach launched boats spread along the coast, worked single handedly on trips of two to five hours duration within three miles of the coast. Cromer beach - renowned by locals and visitors for its 'Cromer Crabs' - has the highest concentration of fishermen (17 boats) with a history going back to the $18^{\text {th }}$ century. Larger harbour boats with a minimum of two men fishing up to 20 miles off the coast on 12 to 24 hour trips have operated from harbours such as Wells-next-the-sea (12 boats) since the 1980s (IFCA, pers comm., 2014). Between 2006-2013, the fishery averaged $\sim 700$ tonnes annually with a value of $£ 2.2$ million, representing 6 per cent of English landings (IFCA, 2013; MMO, 2014). Considered one of the most commercially and culturally important fisheries regionally, it was identified for European Fisheries funding, and the North Norfolk Fisheries Local Action Group (FLAG) was set up in 2011 (FLAG, 2011).

Inshore shellfisheries are currently unrestricted by quota, and access to this fishery has been restricted through boat licences since 1993. Nationally, the level of shellfish and in particular crab exploitation has increased by 40 per cent over the last decade as other fish stocks have declined (MMO, 2014). However, this expansion has mostly been in other parts of the UK rather that in the Norfolk fishery (MMO Statistics, 2014). An 
important difference between this crab fishery and others is that the majority of landings are for the domestic market rather than for export (IFCA, 2013).

Those who continue to fish in North Norfolk today have faced numerous challenges in the past - for instance rising operation costs and the closure of processing factories but they have remained in business by adapting their livelihood strategies. For instance, beach boats have been adapted to reduce crew costs, and fishermen have turned to processing their own catch - often with the help of family members - to increase household income. In this sense, the fishery and its participants can be considered 'socially resilient' - defined as "the ability of a community or of individuals to withstand shocks and stress without upheaval" (Locke et al., 2000, p28). However, a significant present threat to the continuation of the fishery is the lack of new fishermen, particularly of young age, entering the sector as reflected in the FLAG's objectives, aiming to: "Boost entrants - individuals and businesses - to the industry to ensure that the fishery can continue to operate in the long-term" (FLAG, 2011). Less than 20 per cent of fishermen presently working in this fishery are under 30 years old. The risk is that, as existing fishermen retire, the activity will slowly disappear as it has in a nearby coastal town, Sheringham. Crab fishermen have reported good catches and prices in recent years; market demand has been increasing and is not always fully met in the summer months. If there are good commercial prospects in crab fishing, why are there so few new entrants? Why is recruitment failing?

Answers to these questions are complex, requiring the reconciling of sometimes conflicting perceptions of the underlying problem. One factor is quite clear: there has been a downsizing of crews in the crab fishery largely as an adaptive response to the squeeze on profit margins for small-scale producers unable to expand output to meet rising operating costs. As Tom, aged 45, from Cromer explained:

"[We were] always three men in a boat. Now the majority are single-handed boats simply 'cos you can't afford.... You can't get good reliable crew to start with and simply you haven't got to pay anyone then. Whatever you earn is your own. If you got two crew with you, then you've got to work ' $x$ ' amount of pots to make up that money to pay them".

The problem of recruitment, alluded to in Tom's comment, may also be a reflection of changing social culture and different expectations among the young. Carl (65), in conversation with a fellow fisherman, commented: 
“Young people nowadays know that when push comes to shove, they've just got to go and sign on, haven't they? They aren't going to be skint are they? Years ago, you didn't get a lot of help.... Who do you know who is going to stay in the stern of the boat like you used to [when] there's water flying in all directions? Kids won't stick at it will they?"

A rather different perspective was offered by Matt (62) from Cromer concerned with the increasing regulatory and financial obstacles put in the way of young people looking to enter the industry today.

'Years ago you never had to have no 'qualifications'. Now, you've got to have this, that and everything else. That's making it harder for young people to get into [the industry]. Years ago, you got a job as a crewman for a few years on a boat. Then you got enough money to get your own boat and gear and start off on your own. We just learned at sea."

Tim, a young fisherman in his 20s, agreed with Matt but also expressed his frustration at barriers he faced accessing employment. His perception is that older generations are reluctant to transfer access to the fishery to younger generations.

“When you think about it, why should they want young people taking over? They don't want us coming in while they're still fishing. But, yeah, when they're retired, they'll say 'Oh, I wish some young people were coming in!'

However, many older fishermen expressed their wish to see younger generations enter the fishery even if these were from outside their community. Jim, 46:

"We need new blood in the fishing industry. It's a simple as that. Whether it's my family blood or someone else's does not matter. But, l'd like to think that when l'm dead and gone there's still someone doing it"

The opinions of local fishermen cited serve to indicate how recruitment may be enabled or constrained through factors relating to access, and highlights intergenerational tensions. In order to understand the problems of recruitment more fully, the paper examines the processes involved in gaining access to regular employment in the smallscale fishing industry. 


\section{Conceptual framework and methodology}

The conceptual framework is based on Ribot and Peluso's 'theory of access' (2003) where access is 'the ability to benefit from things' - in this case, the ability to earn a living and experience a way of life through crab fishing. This theory was applied to analyse the themes emerging inductively from interviews and grounded in existing literature. Evidence presented in the previous and later sections, indicates that access to employment in fishing is mediated very largely by four factors. First, the legal requirements for working on of board a fishing boat, what Ribot and Peluso would frame as a mechanism of access through 'authority'. Second, relationships with fishermen already working in the industry, termed as 'social relations' by Ribot and Peluso. Third, the availability of employment opportunities ('labour relations') and fourth, sufficient capital to buy and equip a boat ('capital').

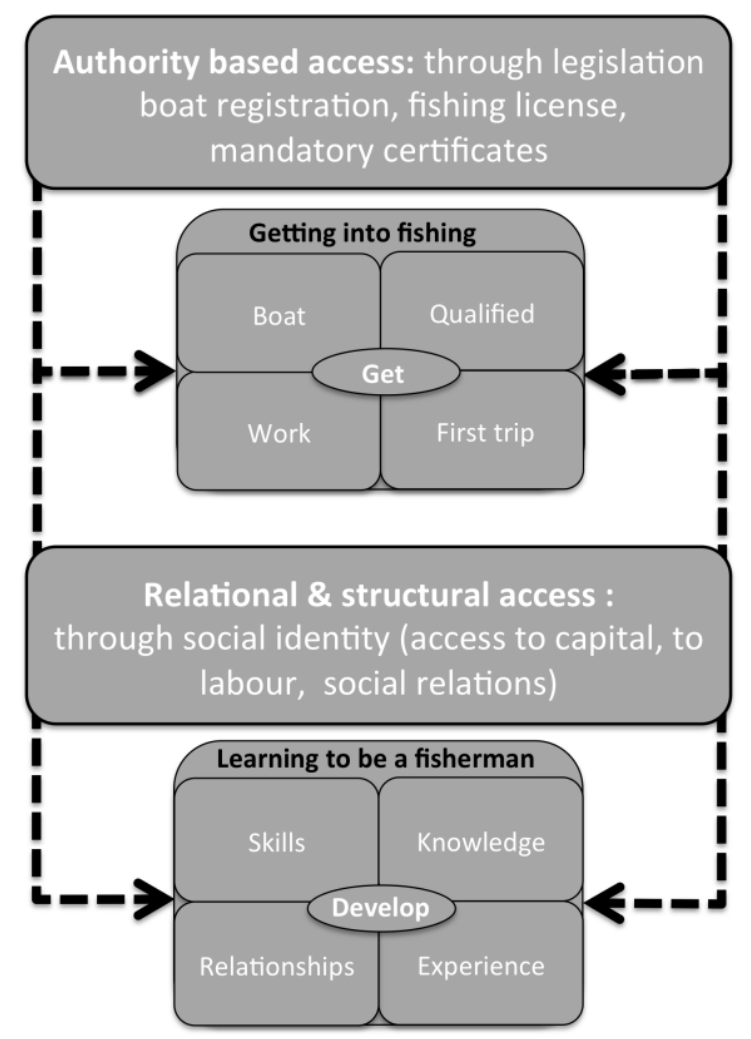

Figure 1 Becoming a commercial fisherman is regulated by authority based access and relational and structural access. These mechanisms mediate how an individual can 'get into fishing' and 'learn to be a fisherman'.

The theory of access characterises rights based mechanisms, as well as factors that mediate access through capital, social identity, labour opportunities and the market, as essential to the understanding of access (Ribot and Peluso, 2003). However, deciding 
to fish or not also depends on access to alternative opportunities and the influence of societal expectations as Johnsen and Vik (2013) found in their analysis of the push and pull factors explaining why fishermen leave the industry. Using the theory of access in this study of recruitment, which focuses instead on those individuals who have decided to pursue a career in fishing, allows attention to be paid to the process of becoming a fisherman and the struggles encountered in accessing the chosen occupation. It considers how agency is constrained by structural and relational mechanisms, which is important for wider debates on social resilience in fisheries, as is elaborated on in the conclusion. Furthermore, particular attention is paid to the importance of kinship ties which in fishing as in farming occupations- recruitment and access to property depends: a boat or land (Gasson, 1969; Acheson, 1981; Miller and Van Maanen, 1982; Symes and Frangoudes, 2001; Lobley and Potter, 2004). On the other hand, fishermen in Kent - mostly first generation fishermen - emphasized knowledge, skill, experience, in explaining successful entry into full-time fishing, rather than social and economic factors linked to kinship (Ota and Just, 2005).

In applying the conceptual framework, (see Figure 1) this paper pays particular attention to the access mechanisms involved in 'getting into fishing' and 'learning to be a fisherman' (Section 4). It then explores the pathways for 'becoming a fisherman' of those with and without kinship ties to fishing (Section 5).

\subsection{Methodology}

A total of 27 in depth interviews were conducted in 2013 and 2014 with active, retired and former fishermen. Snowball sampling was used to identify participants who were selected based on a range of characteristics including age, fishing location, family background in fishing, and variations in livelihood strategy. Most were with beach boat fishermen in Cromer, Sheringham, Cley, Overstrand, and three with harbour boat fishermen from Wells-next-the-Sea and Morston. Ages varied from 19 to 76 years old. Only five were under 30 years old, reflective of age composition in the fishery, where the average skipper age is estimated between 45-55 depending on location. Questions asked related specifically to why and how they got started in fishing, how fishermen are perceived in the community and why young people are no longer entering the sector, along with more general issues such as recent changes in fisheries management. Additional observations were collected through informal conversations on the beach or harbour side, accompanying fishermen on their boats and during shore based activities. Interviews were also held with personnel at the Eastern Inshore Fisheries Conservation 
Authority (IFCA) 2, Wells Harbour Authority, Eastern Seafish Training Association $(\mathrm{ESTA})_{3}$, the Fisheries Local Action Group (FLAG) 4 and the Prince's Trust5. Structured interviews were conducted in the Spring of 2014 with 11 out of 36 people aged between 16 and 25 attending a three week course, 'Get into Fishing', run by the Prince's Trust and funded by the FLAG. Finally, additional data were collected on start-up costs for fishermen using online sales websites and on the number and age of fishermen undertaking mandatory certificates with the regional provider, ESTA. As anonymity was promised, psuedonyms are used to name all respondents and other details such as exact age are blurred. Recorded interviews were transcribed and coded using thematic analysis facilitated through NVivo 10.

\section{Becoming a fisherman}

4.1 Getting qualified and learning to be a fisherman

Obligatory training courses for new entrants were frequently cited as constraining the entry of young people into the industry. In order to go to sea on a commercial fishing boat, the Marine and Coastguard Agency (MCA) requires ${ }^{6}$ all new entrants to have completed a basic one-day course on basic sea survival at a cost of $£ 140$. Within three months of starting work, the completion of three further courses on health and safety is required at a combined cost of $£ 290$. A final course on safety awareness ( $£ 90$ ) must also be undertaken within the first two years of employment. Records collected since 2008 by ESTA, show that of those who completed the final course in Norfolk, only 8 per cent are under 30 , indicating a high drop-out rate within 2 years (ESTA pers comm., 2015).

While skippers of larger boats may be prepared to fund such courses as an investment in good crew relations, the majority are unwilling to do so without any guarantee that the new entrants will remain in their employ. As a result the burden of payment for training will usually fall on the new entrant. At a total cost of $£ 430$ in the first three months of employment, this represents the equivalent of half the monthly starting salary for a deckhand $^{7}$, a substantial investment for a young person still exploring their options.

Additional optional courses are available for more experienced young fishermen, but these will not necessarily increase the chances of gaining regular employment in fishing as 'paper qualifications' tend to lack credibility among older fishermen. Much more importance is placed on experience-based learning and the acquisition of practical skills and personal attributes needed for being a successful fisherman. As Carl (65) observed: 
"I was taught to do things without realising ... That's like when I take my grandson to sea now. I let him steer the boat. He's good at it. He's not aware he's being taught. I'm not teaching 'cos I want to teach him - it's what he wants to do. So if I give him the basic skills and then ... that will be up to him, won't it? But he won't go into it cold. Like my son, I explained to him that, at night, at sea, if something bad happens you need to be able to tie that knot in the dark whatever. I would not let him go out on his own till he could do it with his eyes shut."

Young fishermen learn the dangers of the sea from the skipper they work with, from experiencing and observing different situations and hearing the stories of other fishermen. Jack, 21 , one of the few to crew on a relative's beach boat, related his experience of learning at sea.

"Last year he [the skipper] started letting me take the boat ashore and hauling and baiting up. You start learning different things and picking new things up. So every season I go, I get new things known to me. But the thing is, what I need to pick up is ... all the tides. That's the hardest bit, knowing when the tides are. You got the spring tide, spring ebb, flood tide and all this. They're what you've got to know"

Learning to fish clearly does not rely on universal rules or bodies of knowledge. As the above quotation shows, knowledge of the tides - when they occur and what they mean in fishing terms - must be constantly updated and learned in situ in response to local conditions. Similarly, safety at sea largely relies on the habits fishermen learn to follow and which are acquired through practice, not from a textbook or in a classroom. The increased level of bureaucracy involved in working as a fisherman - of which the introduction of mandatory training courses is often cited as an example - may dissuade new entrants from becoming fishermen. Formal training requirements are seen by fishermen as 'hurdles without meaning' and as undermining the natural process of recruitment.

\subsection{Getting a job: the first trip}

The first important step for any would-be fisherman is to secure his first trip on a working boat. In the past, in the North Norfolk crab fishery, this would normally have been aboard a three man 'crabber', but today it is more likely to be on a beach boat designed for single handed working or on a larger boat working out of a nearby harbour. The initial trip is an 
important test of the working relationship for both the skipper and new recruit. Going on one's first trip is likely to prove a memorable and potentially life changing experience. Nick, a 50-year-old Cromer fisherman, recalled his first trip:

"I started fishing when I was 16. I used to go down the beach when I was a boy and watch the boats going out. It would be first light in the summer around about four o'clock. And he [one of the fishermen] said 'you ought to come one day'; so I went to sea - and it was an easterly [wind]. I was so sick, I laid in the bottom of the boat for about two hours ... but I still kept going."

The maiden trip is likely to be not only an experience and a demanding personal examination, but also potentially a rite of passage proving either the start of a career or a one-off experience. It will test the new recruits' stamina, practical abilities, work ethic and potential to form an effective working relationship with the skipper (Symes and Frangoudes, 2001). It will allow the skipper to make an initial assessment of the recruit's potential skills, personality, reliability and ability to follow orders. As Tim (49) explained:

"Normally if they're [going to be] any good, you can tell it on the first day, or the first couple of days. If they like it, they'll keep going. A lot of them are just like 'Oh, it's a bit wet out here'. The boat's moving and they're a bit sick. But like, the boy Adam, he came round to see my Dad and me and said 'Can I have this job?' We took him to sea, and you can tell within ten minutes... As soon as we started hauling the nets, it was like he'd been doing it for years - and he'd never been out in his life."

"But you can take another and think 'That's a waste of time'. We had a boy down when I was on boats after cod. It was a rough trip and he wouldn't come out on deck. The next day he came in with rubber gloves ... and he said 'I can't go home smelling of fish'. Well, we said 'You're in the wrong job then'. And he never came again."

Regular employment in fishing can be achieved in one of two ways: either as crew for a skipper or being self-employed as a skipper-owner. Working with someone else involves establishing a personal rapport and a sense of trust in order to guarantee the security of medium to long-term employment. However, long-term work opportunities in the North Norfolk crab fishery are scarce. Job vacancies are inevitably limited, especially on beach boats where many fishermen have adapted to work single handedly. As Ben (20) from Cromer explained: 
"They keep saying [that] there's no young people coming into the job anymore. But there is youngsters coming into it, 'cos I know a few of my mates who would come and do it. But ... all the boats off Cromer, they are single-handed. They don't take anyone on. If someone comes down there and says 'Can I come to sea with you?' they would say 'Well, no. I go on my own'. They're not looking for a crew. That's where it's all going to die."

Access to permanent employment is clearly limited by declining job opportunities. This lack of opportunity for all but a few means that in order to fish on a regular basis sufficient to earn a living - the aspiring young fisherman must look to the second route into a fishing career: owning his own boat.

\subsection{Getting a boat}

The prospect of finally owning a boat, becoming independent and being one's own boss is one of the attractions of fishing that fuels the ambitions of most young recruits, at least on inshore vessels. Becoming a skipper involves acquiring the material assets and capital needed for going fishing - vessel, gear and licence. Estimates of the cost involved vary between about $£ 28,000$ and $£ 42,000$ for a beach boat ${ }^{8}$ and in the region of $£ 150,000$ to $£ 200,000$ for the larger crabbers fishing from harbours like Wells. Because of the level of financial investment involved, the transition from deck hand to skipperowner usually occurs later in a fisherman's career, after he has amassed some savings. With limited opportunities for crewing on the beach boats, the option of becoming a skipper-owner may be the only - albeit expensive- means of accessing permanent employment. Boat and gear are commonly acquired second hand, usually through the Internet or by word of mouth, and often without the use of a loan. On the subject of loans, Tom (45) who previously worked from Wells and now fishes from Cromer commented:

"The thing is once you mention you're a fisherman everything is more expensive ... It's like life insurance, once you say you're a fisherman ... that's suddenly a lot more money ... And that works the same with loans. But then, would you want to borrow $£ 100,000$ ? You're not guaranteed what you are going to catch and you still have to pay the loan back."

Having all the equipment necessary for going to sea is not enough to be able to fish commercially. The boat must also have the appropriate licence; varying in cost according to vessel length and width and engine capacity and ranging from between 
$£ 3,500$ for a 16 foot boat $(4.88 \mathrm{~m}$ ) with a $15 \mathrm{hp}$ engine to $£ 10,000$ for a 21 foot boat $(6.40$ $\mathrm{m})$. If a boat is sold without a licence, its acquisition can be problematic as numbers were capped by national government in 1993. Since no additional licences can be issued, the would-be skipper must obtain his entitlement from an existing licence holder. The licence specifies the size and engine capacity of the boat. In addition, the type of fishing is specified- in the case of crab- by a shellfish permit since 2004. Should a vessel owner wish to increase his fishing capacity he would need to find a way of modifying the existing licence, usually through acquiring an additional entitlement. Licence aggregation is subject to a penalty whereby the new capacity will be less than the sum of the two original boats. As Bill (50) explained:

"[The fisheries department] issued licences. And then one of the boats wanted to buy a new engine and they said 'No, the licence is only valid for the horsepower you've got.' So someone, in their wisdom, said 'l've got $x$ amount of spare capacity on my licence, so I'll sell it to you for a fee' and, all of a sudden, licences started to have a value. They were given away for free at first but then someone realised there was [money] to be made."

Having a licence has become an investment that is worth holding onto, increasing in value as they became scarcer. While this may be a sign that the policy goal to reduce fishing capacity is working, it conflicts with other goals to sustain thriving fishing communities. Upcoming government plans to remove what is considered 'latent capacity' will only accentuate this further. The price of a licence now often exceeds the cost of a boat, adding to the financial burden and threatening to price many aspiring skipper owners out of the market.

\section{Pathways to becoming a fisherman}

Ease of entry into fishing depends to a large extent on whether the would-be fisherman comes from a fishing or non-fishing background. As with a farming livelihood, the conventional path for young people to enter fishing was, either directly through succession and inheritance or indirectly through wider family based social networks (Symes and Frangoudes, 2001; Johnsen, 2004). The would-be fisherman would learn the requisite skills and knowledge of the local fishery, starting from an early age, on board his father's boat, eventually taking over as skipper and finally inheriting the family's fishing enterprise. For those not from fishing families it was more a matter of persistence, hanging around the beach, making oneself useful and waiting for a vacancy to come up. 
Failing that, skippers from nearby larger ports - Lowestoft, Great Yarmouth and King's Lynn - would from time to time need crewmen for their trawlers. While the basic pathways remain in place today, circumstances have changed and opportunities have become more limited. New pathways, through apprenticeship schemes and training programmes, are also beginning to open up (discussed in 5.3).

\subsection{The hereditary pathway}

The customary pathway whereby sons would follow fathers into fishing is no longer as straight forward as it once appeared. Social change - most notably in the form of improved education provision and increased social and spatial mobility - have widened the job aspirations of young people and their parent's expectations. As Tony put it, 46 "I'd rather [my son] be a doctor or a solicitor or you know, a really highly paid sort of blokey so he can look after me when I get older." There is also evidence elsewhere that fishing is no longer seen as an occupation that offers sufficient status, financial rewards or job security as in former times (Williams, 2008; Trimble and Johnson, 2012; Power et al.,, 2014). As in other rural places, young people tend to leave as young adults to look for opportunities elsewhere (Glendinning et al., 2003; Bjarnason and Thorlindsson, 2006).

Socialisation into fishing by family was the common experience of many existing fishermen in North Norfolk, and it occurred at an early age. David (45) for example recalled that he had gone to sea 'in his father's arms'. The majority of those now in their 40 s or older started fishing at the age of 15 or 16; Bill (48) explained:

"I started straight from school. I never had [another] job. My father gave me jobs. He would say 'what are you doing at school today, boy?' So I said PE (Physical Education). 'You're not going to that bloody thing; you can come and bait some lines for me!' So I used to bait long lines ... l'd always be doing things for him. I was under his shadow for a long time."

Today, there is no longer overt pressure from within the family to persuade sons to follow their fathers onto the family boat (though in private many would probably be proud to see them do so). Indeed, few of those interviewed were keen to encourage their sons to go fishing. Fishermen's daughters have never been expected nor encouraged to work on fishing boats. Asked whether, if he had sons, he would encourage him to take up fishing, Will (47) who has several daughters replied: 
"I don't know. A lot of fishermen don't. They don't encourage them nowadays. Years ago they were more or less made to go ... but now, like Jim's son and Dave's son [they] don't go. And Tony, I don't know if his son will go. He was the one that for a while back looked like he was."

With so many sons now pursuing other options, the future sustainability of the beach boat crab fishery in Cromer looks uncertain. David, a 75 year old retired fisherman from Cromer, when asked what he thought would happen in the future was pessimistic in his outlook: "No, I don't think there'll be many more at Cromer to be honest, because the fisherman who has got sons - they're not going to sea now". He didn't expect their places to be taken by men from non-fishing families. In this last respect, David seems to be unaware of, or unwilling to accept, the transformational change already occurring in the North Norfolk crab fishery - namely that the widely held view that social reproduction in small-scale fisheries relies heavily on the processes of succession and inheritance occurring within a largely closed network of fishing families is beginning to lose its relevance. Those aspiring to become fishermen may increasingly come from outside the fishing community, as has been observed in other fisheries and rural areas (Ota and Just, 2008; de Lima and Wright, 2009).

\subsection{The non-hereditary pathway}

While fishing is often understood to be passed from father to son, of the 15 skippers fishing from Cromer beach in 2014 , only a third have a family history of fishing stretching back more than two generations. Six are first generation fishermen and four are second generation. Moreover, of the five young fishermen interviewed none had succeeded their fathers, though two had more distant family connections with the industry. This challenges the assumption that fishing must necessarily be an inherited way of life. For an increasing number of would-be fishermen, therefore, the more difficult, non-hereditary pathway provides the only means of entry to the industry. The problems they face are considerable, not simply in terms of the financial costs involved in acquiring and fitting out the boat (see Section 4.3 above). Without kinship ties in the fishing community, they may find it more difficult to find a skipper willing to 'teach them the ropes'. As a participant on the 'Get into Fishing' programme explained:

"The fact is that ... if you don't come from a fishing background you can't say 'Oh, my dad's a fisherman [or] my Grandad [was] a fisherman' no one will give you respect." 
Expressing some form of social connection or identification with the fishing community through family or friends - is an important way into the job.

Climbing the ladder For those attempting to make a career in fishing there are several options - none of them easy - as the life histories of those who have entered a career in fishing following the non-hereditary pathway over the past 30 or 40 years reveal. Building up from a deckhand to a skipper-owner is the most common one.

A Sheringham skipper, now retired and with no family history of fishing, recounted his own experience of progressing to the status of skipper-owner:

"I was never hardly at school. I was always on the beach, alright. When I left school I went and done of bit of other work, and [then] the opportunity arose that I could go to sea ... In them days there was either two brothers and a father in the boat or what we called a paid hand. And [jobs] were very hard [to find] because obviously ... unless one died you wouldn't get in the boat. [Then] one of the old boys was going to finish and I bought his crab pot gear and I went as a full-time fisherman. And, of course, it just grew from there ... But before that, I was a paid hand"

Still today, one of the strategies of fishermen is to buy their own gear as they earn. Tim (20) had been working as a deckhand on a Wells boat for a few seasons and was saving up. He had invested $£ 2,500$ in purchasing crab pots and was planning to save up for more. Having his own gear meant that he could start earning extra money on top of his pay as a deckhand, as anything caught with his pots would be sold in his name. At the same time, buying his own gear shows commitment in his future and the plan one day to have his own boat or buy his skipper's boat. He was intent on buying all he needed rather than taking out loans which was considered a risky strategy:

"People that buy boats nowadays, they take out big loans to get them. Obviously they've got to work hard to pay off those loans. I don't want to be doing it with that over my head, because obviously if I'm new to the job [of being skipper-owner] and I don't go and catch as much as the others ... then l'm going to have bailiffs and God knows what after me. Hopefully, if [my boss] does say 'Oh, you can take my boat' he might let me pay for it as I earn. So when I save up, then [I can] pay him off or something like that."

Working part-time Earnings from fishing are notoriously unreliable: income varies from year to year according to season which lasts on average from March to October with 
months without revenue. With a family to support and a mortgage to be repaid, some fishermen may choose to fish part-time, and combine jobs. Examples include working away for a few weeks offshore for wind energy companies or working part of the day in construction or for the post office. Going to sea is a means of increasing earnings and building up savings necessary to eventually work full-time fishing. This strategy tends to be more common among relatively older recruits with some capital saved up but with dependents to support. As Ota and Just (2005) also noted in Kent, the extent to which this strategy of part-time fishing leads to a full-time transition into fishing is questionable.

Boat hopping: In order to broaden their experience young fishermen may opt to work on different boats whether from harbours or from the beach. Opportunities for employment are generally greater in the larger harbours. As Tim from Wells Harbour (48) commented:

"The boats at Wells require a lot more crews than the beach boats. They come and go. I always refer to them like footballers in a football team. They just jump from boat to boat, the younger ones... And, eventually they are on the top boats that everybody wants to be on."

Fishing from Wells is very different to fishing from the beach at Cromer -physically more demanding, 'a young man's game', but with the chance of being able to afford to buy one of the larger crabbers at over $£ 100,000$ much more remote. For entrants from nonfishing backgrounds, therefore, one route to skipper-owner status possibly lies in learning to fish from a harbour such as Wells. Later in their career with years of experience and accumulated savings in the bank, they may move into the beach fishery with a boat of their own, continuing in a smaller scale of fishing for as long as they have the physical strength and the will to do so. However, the insecurity of working as crew and the length of time necessary to become a skipper-owner may lead to discouragement particularly as fishermen start families. As Vik and Johnsen (2013) also found, regular work hours and time with family were common reasons in decisions for leaving fishing.

\subsection{Assisted entry: unlocking the door?}

In Section 4.1, reference was made to the financial hurdles immediately placed in the path of the would-be entrant in relation to mandatory certification prior to and during the first year of employment in fishing. In some instances funding for training and gaining experience with fishermen may be available through volunteering for service in the Royal 
National Lifeboat Institute (RNLI). Recently, national concern over high levels of longterm youth unemployment in the economy at large has prompted formal attempts to improve basic skill levels and provide apprenticeship schemes that can lead into permanent employment. In the fisheries sector, government led apprenticeship schemes have focused on fish processing or aquaculture rather than the catching sector. In 2013 and 2014, the Prince's Trust ran a programme in North Norfolk called, 'Get into Fishing', co-funded with the FLAG to address this gap. The latter offers three-week courses to unemployed youth on mandatory training, food hygiene, engine maintenance and boat handling with rather less than a third of the time of practical experience on board a boat. Thus, despite the best of intentions, the impact of such schemes on the recruitment of fishermen is slight, principally because they can do little to improve access to employment on a boat locally.

The frustration felt by one of those attending the 'Get into Fishing' scheme was clear.

"[It] did help me get qualified, you know; but that's the problem because they give everyone qualifications to go and work on a boat but none of them ... have got work on a boat. So the Prince's Trust has wasted that money training them people..."

Just as clear is the scepticism towards apprenticeships felt by those already in the industry. Jim (49) a beach boat skipper summed up the situation quite neatly:

"This apprenticeship idea is a nice idea and you can teach them how not to sink or how to tie a knot, but you can't teach them [to fish]. The only way they would learn is to actually come to sea. We used to have the double ended crab boats which were bigger than the ones we use now. You can do it with two of you but [today] you have your 'slave hauler' [that] does the work of one man and everything is positioned and set up to work one handed. When Jack [my son] does come to sea with me I find him things to do, but it's difficult to keep him interested for the whole trip."

Funded training programmes cannot guarantee entry into employment. They may be useful in providing a young person with no previous background in fishing with the opportunity to familiarise themselves with some aspects of the occupation and to acquire basic entry level qualifications. Ultimately, strong determination is needed to succeed in what is now principally a vocational career choice. To a limited degree, they offer participants certain advantages, to the extent that a potential employer has the assurance that they have the minimum legal qualifications for working at sea. The final 
problem, however, remains access to permanent employment, that is the lack of jobs within the local industry itself and the reluctance of local skippers to provide work experience in a fishery that is increasingly designed to operate with reduced crew sizes. 6. Conclusion

What can this study of the North Norfolk crab fishery tell us about recruitment, social reproduction and the future resilience of small-scale fisheries more generally? Although the details will no doubt vary from fishery to fishery, anecdotal evidence and other published work would suggest that similar issues are to be found elsewhere in European coastal fisheries (Williams, 2008; Sønvisen et al., 2011; Britton, 2012). Hitherto, the resilience literature on fishing communities has focused on livelihood adaptation strategies at the household level and on the capacity for collective action. It has tended to ignore the crucial individual decision making involved in career choice and, more especially, access into working as and becoming a fisherman - arguably the single most important process in ensuring social reproduction and maintaining the resilience of smallscale fishing. This paper has used the theory of access to highlight how individual agency is constrained or enabled by structural mechanisms. In doing so, it includes a consideration of agency in social resilience as called for by Coulthard (2012) and Davidson (2013). In particular, this study highlights intergenerational issues of access, which impact on the social resilience of the fishery.

In analysing the recruitment of young people to the North Norfolk crab fishery, this paper has focused on concerns over access to the fishery at three distinct stages of becoming a fisherman: qualification, involving a significant but not insuperable financial cost; first time entry into fishing employment, made more difficult by changes to fishing practice that imply diminishing prospects for job opportunities; and, after gaining sufficient practical experience, the acquisition of one's own boat, that marks the culmination of becoming an independent fisherman. Funded programmes for training have attempted to facilitate recruitment at the first stage. However, the major pinchpoints in the recruitment process remain: entry into fishing employment and boat acquisition. At later stages, mechanisms of access mediate how new fishermen can make a living including accessing markets, a topic for future work which is not discussed here.

Access is becoming more, rather than less, restricted through a lack of initial job opportunities and the rising costs of owning one's own boat. Making a living from smallscale fishing has become increasingly difficult. As Johnsen and Vik (2013) found many fishermen leave the industry due to financial reasons and are attracted to jobs in offshore 
sectors, which offer greater income security and regular hours. There are parallels between fishing and farming which suggest a wider crisis of youth employment in rural areas (Bjarnason and Thorlindsson, 2006) and a disinterest among young people in rural jobs. White (2012) highlights the government's neglect of small-scale rural sectors and infrastructure, the deskilling of rural youth, and the problems the rural young face in gaining access to livelihood assets, controlled by intergenerational transfer.

While the present generation of North Norfolk crab fishermen recognises the extent and possible consequences of recruitment failure, many remain wedded to the notion of fishing as a family business - even among those from non-family backgrounds and where their own sons are opting out of fishing as a career. In the past, it was assumed that access to employment in fishing was mediated through relational mechanisms implicit in networks of fisher households, fishing crews and fishing communities. Weaknesses in this assumption are increasingly being exposed as they already have in other fisheries (Miller and Maanen, 1982; Ota and Just, 2008). A key function of the fishery's social system: to ensure social reproduction of fishing enterprises (Symes et al., 2015 this volume), is being progressively undermined through a combination of social change and regulatory intervention. The implications are that in future generations more potential recruits may come from non-fishing backgrounds. In an increasingly mobile world, the potential for new recruits to come from communities further afield with fishing traditions is real and has been observed historically (Miller and Van Maanen 1982; Symes and Frangoudes, 2001). Migrants are likely to face a number of structural, financial and attitudinal obstacles to accessing employment in rural industries, however they may also be more determined (de Lima and Wright, 2009). Unless conditions of access for local recruits are improved, the long term future of beach based crab fishing will remain bleak with the likelihood that fishing entitlements will eventually be sold out of the community.

There is clearly a need for more detailed understanding of the evolving circumstances surrounding recruitment, how policy changes have impacted on normative processes of social reproduction and, in response to such developments, how policy makers should respond. So far, the scope for policy intervention is strictly limited and confined largely to financial assistance. At the EU level, this is recognised principally in the new European Maritime and Fisheries Fund (EMFF) ${ }^{9}$, from 2014-2020. Financial provisions are provided by Article 29 for apprenticeships while Article 31 endorses start-up support for young fishermen with at least five years employment in the industry. However, the recruitment problems, such as those facing the North Norfolk crab fishery, cannot wholly 
be solved through simple technical fixes. Furthermore, sectoral approaches alone are likely to be too narrow. As Johnsen and Vik (2013) concluded the issues around recruitment in fishing are also connected to challenges in the wider coastal rural economy. Power (2012) suggests that policies should support occupational plurality and seasonal employment.

Action is required on several levels. One is direct legislative provision by the EU and the Member States mentioned above. The second involves the implementation of measures through well-designed local initiatives to improve recruitment. These may be best accomplished within a framework of broader initiatives intended to secure local sustainability and resilience. Two particular forms can be cited here: community based management schemes where participants' fishing entitlements may be pooled and some part of the aggregate entitlement set aside to assist the access of new entrants; and, initiatives building on those such as the FLAG which will in the future be required to develop integrated multisectoral strategies for local fisheries related development (see papers by van de Walle and Phillipson and Symes in this volume). A recognition that individuals may come from a larger geographical area may mean broadening the scope and support of any future initiatives aimed at encouraging long-term recruitment in the industry. Attention must be paid to how access is limited by boats in different fisheries to their demographic component and the particular nature of recruitment. For instance, more opportunities for young people may exist on larger boats but may involve shorter careers. On the other hand, access for young people into the beach fishery has been limited by the move towards one-man operations that continue to fish into retirement age. Any policy intervention must be careful not to only incentivise recruitment onto larger boats, but to also address the more difficult recruitment issues of smaller boats. In Norway for example, a youth quota has been implemented with some encouraging signs (Power, 2012). This could be designed to respond to the particular demographic context of different fisheries.

The paper has raised questions about recruitment into small-scale fishing. If maintaining small-scale fisheries is a policy objective, then ensuring recruitment is crucial to building future resilience. To a degree, resolving the underlying issues will also require a conscious effort on the part of those presently engaged in the industry to create space for the incoming generation. Any interventions aimed at addressing the issues of recruitment at a local level must therefore include current fishermen from the outset. Finally, addressing the issue of rural youth employment will require a coordinated holistic 
approach to rural development approach, investing in infrastructure more broadly and valuing rural livelihoods.

\section{Acknowledgments}

This work would not have been possible without the Norfolk fishermen who willingly took time to participate in this study, which was part of $\mathrm{PhD}$ research funded by the Centre for the Environment, Fisheries and Aquaculture Sciences (CEFAS). Thanks also to the Prince's Trust and Eastern Sea Fisheries Training for facilitating contact with trainee fishermen. I would like to thank my supervisors at the University of East Anglia: Eddie Allison, Laura Camfield, Tim Daw and Catherine Locke for their comments on early and revised drafts of this paper and Steve Mackinson at CEFAS for his ongoing support. Thanks to Rodd Myers for insightful discussions on the theory of access. Finally, thanks to David Symes and Jeremy Phillipson for the opportunity to present this work at the European Rural Sociology Congress in July 2013 and for their helpful advice with the final draft.

\section{References}

Acheson, J.M. (1981) Anthropology of Fishing. Annual Review of Anthropology (10): 275316

Britton, E. (2012) The 'having, doing and being' of fishing well: assessing the social wellbeing of Northern Ireland's fishing households in a changing coastal environment. (PhD thesis, University of Ulster). Available online http://catalogue.library.ulster.ac.uk/items/1345163?query=britton\&resultsUri=ite ms\%3Fquery\%3Dbritton\%26sort\%3Dpublishedyear\%253Ad\&sort=publishedye ar\%3Ad

Bjarnason, T. and Thorlindsson, T. (2006) Should I stay or should I go? Migration expectations among youth in Icelandic fishing and farming communities. Journal of Rural Studies 22 (3) pp. 290-300.

Coulthard, S. (2012) Can we be both resilient and well, and what choices do people have? Incorporating agency into the resilience debate from a fisheries perspective. Ecology and Society 17(1) pp 4.

Davidson, D. J. (2013) We Still Have a Long Way to Go, and a Short Time to Get There: A Response to Fikret Berkes and Helen Ross. Society and Natural Resources, 26 (1) pp.21-24 
de Lima, P; and Wright, S. 2009. Welcoming Migrants? Migrant Labour in Rural Scotland. Social Policy and Society 8 (3) 391-404

ESTA 2015 pers comm., by email on $2^{\text {nd }}$ February 2015. Anonymised data from training records of fishermen in the East of England.

Fisheries Local Action Group (FLAG). Axis 4 Programme Complement Doc 1. Summary North Norfolk FLAG Programme. August 2011

Gasson, R. (1969) The choice of farming as an occupation. Sociologia Ruralis 9 (2) pp.146-166

Glendinning, A., Nuttall, M., Hendry, L., Kloep, M. and Wood, S. (2003) Rural communities and well-being: a good place to grow up ? The Sociological Review 51(1) pp.129-156

Hatcher, A.C. (1997) Producers' organizations and devolved fisheries management in the United Kingdom: Collective and individual quota systems. Marine Policy 21 (6) 519-533

IFCA (2013). Chapter 4: Crab/Lobster Stock Assessment. Pp. 142-182 in Research report 2013. Available: http://www.easternifca.gov.uk/documents/Annual\%20research\%20report\%202013.pdf

IFCA (2014) pers comm. Fleet list for North Norfolk by email on $13^{\text {th }}$ June 2014.

Johnsen, J.P., Vik, J. (2013) Pushed or pulled? Understanding fishery exit in a welfare society context, Maritime Studies 12 (4) pp.1-20

Johnsen, S. (2004). The redefinition of family farming: agricultural restructuring and farm adjustment in Waihemo, New Zealand'. Journal of Rural Studies 20 pp. 419-432

Lobley, M. and Potter, C. (2004). Agricultural change and restructuring: recent evidence from a survey of agricultural households in England. Journal of Rural Studies 20 (4) pp. 499-510

Locke, C., Adger, N.W. and Kelly, P.M. (2000) Changing places: Migration's social and environmental consequences. Environment 42 (7) pp.24-35

Miller, M.L. and Van Maanen, J. (1982) Getting Into Fishing: Observations on the Social Identities of New England Fishermen. Journal of Contemporary Ethnography 11 (1) pp. $27-54$

MMO (2014) The UK Sea Fisheries Statistics 2013. Annual publication. Available: https://www.gov.uk/government/uploads/system/uploads/attachment_data/file/3 58342/UK_Sea_Fisheries_Statistics_2013_online_version.pdf

MMO Statistics (2014). Accessed online data tables, 10 ${ }^{\text {th }}$ September 2014 Available: http://webarchive.nationalarchives.gov.uk/20140507202222/http://www.marine management.org.uk/fisheries/statistics/annual_archive.htm. 
NEF (2012). Jobs lost at sea. Overfishing and the jobs that never were. Available http://www.neweconomics.org/publications/entry/jobs-lost-at-sea

Neis, B., Gerrard, S. and Power, N.G. (2013) Women and Children First : the Gendered and Generational Social- ecology of Smaller-scale Fisheries in Newfoundland and Labrador and northern Norway. Ecology and Society 18 (4) pp. 64-76

Ota, Y. and Just, R. (2008) Fleet sizes, fishing effort and the "hidden" factors behind statistics: An anthropological study of small-scale fisheries in UK. Marine Policy 32 (3) pp.301-308

Phillipson, J. and Symes, D. (2015) Finding a Middle Way to Develop Europe's Fisheries Dependent Areas: The Role of Fisheries Local Action Groups. Sociologia Ruralis, this issue

Power, N.G. (2012) Is there a place for youth in fisheries communities? A multiple perspectives discussion Workshop Synthesis Report. Community-University Research for Recovery Alliance (CURRA). http://www.curra.ca/documents/Presymposium\%20youth\%20workshop\%20synthesis\%20report\%20FINAL.pdf

Power, N. G., Norman, M. E. and K. Dupré. (2014) "The fishery went away": The impacts of long-term fishery closures on young people's experience and perception of fisheries employment in Newfoundland coastal communities. Ecology and Society 19 (3) pp. 6.

Ribot, J.C. and Peluso, N.L. (2003) A Theory of Access. Rural Sociology 68 (2) pp.153181

Sønvisen, S.A., Johnsen, JP and Vik, J. (2011) The Norwegian coastal employment system: What It Was and What It Is. MAST 10(1): 31-56

Sønvisen, S.A., 2013. Recruitment to the Norwegian fishing fleet: storylines, paradoxes, and pragmatism in Norwegian fisheries and recruitment policy. Maritime Studies 12 (8) pp. 1-26

Symes D. and Frangoudes K. (2001) The social organisation and reproduction of Inshore fishing. Pp. 159-175 in D. Symes and J. Phillipson (eds), Inshore fisheries management (Dordrecht: Kluwer Academic Publishers)

Symes, D. and Phillipson, J. (2009) Whatever became of social objectives in fisheries policy? Fisheries Research 95 (1) pp.1-5

Symes, D; Phillipson, J. and Pekka S. (2015) Europe's coastal fisheries: instability and the impacts of fisheries policy. Sociologia Ruralis, this issue

Trimble, M. and Johnson, D. (2013) Artisanal fishing as an undesirable way of life? The implications for governance of fishers' wellbeing aspirations in coastal Uruguay and south-eastern Brazil. Marine Policy (37) pp.1-8 
van de Walle, G., Gomes da Silva, S., O'Hara, E. and Soto P. (2015) Achieving sustainable development of local fishing interests: the case of Pays d'Auray FLAG. Sociologia Ruralis, this issue

White, B. (2012) Agriculture and the Generation Problem: Rural Youth, Employment and the Future of Farming. IDS Bulletin 43: 9-19.

Williams, R. (2008) Changing Constructions of Identity : Fisher Households and Industry Restructuring. (PhD thesis, Newcastle University) 


\footnotetext{
${ }_{1}^{1}$ All fishers currently participating in the fishery are male. The term fishermen is therefore used. This only includes data from harbours and beaches in the district of North Norfolk.

2 The Inshore Fisheries and Conservation Authority has devolved powers from national government for the management and conservation of the marine environment and for enforcement of law in the inshore area.

3 Eastern Sea Fisheries Training is a training provider for the seafood industry in the East of England accredited by the public industry authority, Seafish.

4 The North Norfolk Fisheries Local Action Group (FLAG) is a partnership between fisheries actors and other local private and public stakeholders to allocate funds from Axis 4 of the European Fisheries Fund. 5 A UK charity which supports 13 to 30 year-olds who are unemployed and those struggling at school and at risk of exclusion

${ }^{6}$ Legal requirement under The Fishing Vessels (Safety Training) Regulations 1989 amended in 2004 by Statutory Instrument No. 2169

7 The National Careers Service suggested that the starting salary for a deckhand is $£ 10,000+$ per year. Crew on board Wells vessels can expect $£ 100$ per trip and crew on beach boats around $£ 50$. Usually no income is received when the boat does not go to sea.

https://nationalcareersservice.direct.gov.uk/advice/planning/jobprofiles/Pages/fishingvesseldeckhand.aspx Accessed on 12/06/2014.

8 Beach boat including engine $=£ 9500-15000$; fishing gear (pots, pot anchors and slave pot hauler) $=£ 10000-12000$; shore based equipment (tractor, trailer) $=£ 4500-6000$ and a licence $=£ 3500-10000$. Source: interviews and www.findafishingboat.com

${ }^{9}$ Regulation No 508/2014 of the European Parliament and of the Council of 15 May 2014 on the European Maritime and Fisheries Fund
} 